This is the final peer-reviewed accepted manuscript of:

Fighting nuclear proliferation through education. The remarkable story of ISODARCO by Paolo Foradori and Giampiero Giacomello in Modern Italy, 2018, vol.23 issue 3; 331-344 pages.

The final published version is available online at:

http://dx.doi.org/10.1017\%2Fmit.2018.17

Rights / License:

The terms and conditions for the reuse of this version of the manuscript are specified in the publishing policy. For all terms of use and more information see the publisher's website.

This item was downloaded from IRIS Università di Bologna (https://cris.unibo.it/)

When citing, please refer to the published version. 


\section{Fighting nuclear proliferation through education. The remarkable story of ISODARCO}

\author{
Paolo Foradori $^{* 1}$ and Giampiero Giacomello ${ }^{* 2}$ \\ ${ }^{1}$ School of International Studies, University of Trento, Trento, Italy \\ ${ }^{2}$ Department of Political and Social Sciences, University of Bologna, Bologna, Italy
}

(Received 18 May 2017; final version accepted 30 March 2018)

Disarmament and non-proliferation education is a key tool in curbing the spread of nuclear weapons, with a view to their elimination. This article examines the remarkable story of the International School on Disarmament and Research on Conflicts (ISODARCO) on the occasion of its fiftieth anniversary of continuous engagement in educational and training activities. ISODARCO offers a unique forum where nuclear experts from different backgrounds and approaches can meet, debate, and promote action as a transnational knowledge-based network of experts and, equally important, pass on their expertise to the 'next generation of non-proliferation specialists'. The contribution of this small Italian NGO is indeed noteworthy, highly praised at the national and especially international level, and worth the attention of an audience broader than just non-proliferation and security experts.

Keywords: non-proliferation; disarmament; nuclear weapons; education; NGO (1)

\section{Introduction}

This article examines the important contribution of the International School on Disarmament and Research on Conflicts (ISODARCO) in combating the spread of nuclear weapons and in promoting the objective of their elimination during its 50 years of continuous engagement in disarmament and non-proliferation education (DNPE). Founded in 1966, ISODARCO offers a unique international forum on global security-related problems, where experts on nuclear issues from different backgrounds and approaches can meet and interact and, equally important, pass on their expertise to younger researchers and scholars, the so-called 'next generation of nonproliferation specialists'. This contribution has been praised by no less than US President Barack Obama, who personally greeted ISODARCO on the occasion of its fiftieth anniversary, stating that 'you are helping reduce the possibility of catastrophe and contributing to better understanding among peoples and states. As you reflect on your achievements, I commend you for your efforts and wish you the best for the years to come'. ${ }^{1}$ Equally appreciative and laudatory have been the acknowledgments by Sergio Mattarella, President of the Italian Republic, who in 2017 granted ISODARCO the Gold Medal for its public service and promotion of Italy's cultural contribution in the world. ${ }^{2}$

The significant role played by this small Italian NGO is little known outside the nonproliferation community and is worth being investigated and told to a larger audience. To that end,

*Emails: paolo.foradori@unitn.it; giampiero.giacomello@unibo.it 
the article is divided into three parts. The first section recalls the history of ISODARCO, looking into its origins, motivations, and objectives. The second part discusses the contribution of ISODARCO in terms of a transnational network of knowledge-based experts and argues how such an expert community can indeed support international efforts to enhance national and international security at lower levels of armaments and ultimately lead to general and complete disarmament under effective international control. Focusing on the relevance of DNPE as a fundamental tool in curbing the spread of nuclear weapons, the third part examines ISODARCO's educational activities and highlights the distinctive features of its approach. The conclusion provides some final remarks on this extraordinary experience, which has brought together thousands of nonproliferation experts, younger scholars, and students committed to the common mission of creating the conditions for a world free of nuclear weapons.

40

41

42

43

44

45

46

47

48

\section{A very short history of a brilliant idea}

For a country that does not possess a nuclear arsenal, Italy's interest in and attention to nuclear weapons has been quite remarkable. Among the major European countries, given the United Kingdom's and France's unremitting commitments to their own arsenals, only modern Germany comes close to matching it. In part, as in Germany, the depth of Italy's interest is due to the longstanding presence of this type of weapon on its soil, deployed by the United States throughout the Cold War and afterwards as part of NATO's nuclear sharing arrangements (Foradori 2013). It is also a by-product of the Italian school and tradition of nuclear physics. Enrico Fermi might have fled Italy and worked on the Manhattan Project, but his opposition to this class of weapons was not lost on the 'ragazzi di via Panisperna' - the students whom he inspired in the 1930s - who went on to secure a prestigious position for the discipline of nuclear physics within Italian academia.

In the early 1960s, the idea for an organisation such as ISODARCO arose thanks to two great Italian physicists, Edoardo Amaldi and Carlo Schaerf, in a conversation during a residential course at the Italian Physical Society in Varenna, on Lake Como (Schaerf 2018). Amaldi was one of Fermi's original 'ragazzi' who had worked to re-establish Italy's scientific standing after the Second World War, contributing to the founding of the European Organization for Nuclear Research (today known as CERN) and of the European Space Agency (ESA). Schaerf was a junior scientist, at the time working in Wolfgang K.H. Panofsky's laboratory at Stanford University, who, almost singlehandedly, carried ISODARCO beyond its fiftieth anniversary.

It was a time when both superpowers were fast expanding their arsenals, with the United States in the lead (with nearly 29,000 nuclear devices in 1963) and the USSR (with roughly 4,200) fast catching up (Norris and Kristensen 2010). The Berlin and Cuban crises had just happened and a confrontation between NATO and Warsaw Pact was a real possibility: Amaldi was deeply concerned about such a nuclear arms race. The most influential scientist in Italy at the time (Rubbia 1991), he was also a member of the Continuing Committee of the Pugwash Conferences on Science and World Affairs. ${ }^{3}$ Inspired by the residential course structure (junior and senior scientists sitting together at lectures and discussing for one to two weeks) and Schaerf's similar experience at Stanford (particularly in the Faculty Forum on Arms Control held once a month with top experts), the two physicists conceived the project of organising a residential course on the science and technology of the arms race and the use of nuclear arsenals in war. They were both very aware that the nuclear age and international security called for a wealth of scientific and technical knowledge unavailable to policy-makers, journalists, and academics, let alone the general public. Following the well-known aphorism of French President Georges Clemenceau that 'war is too serious a business to be left to generals', Amaldi and Schaerf laid the groundwork to overcome that gap. 
It took them three years after Schaerf's return from Stanford in November 1963 to organise the first course. It was held at the Villa Falconieri in Frascati (Rome) from 13 to 25 June 1966, with nine lecturers, three visiting officials, 23 participants, and seven observers. It was funded with a grant from the Geneva office of the Carnegie Endowment for International Peace, and support from the Italian government. The discussion focused on the effects of nuclear weapons, nuclear strategy, and world security, as well as the economic aspects of disarmament, and the prospects for peaceful coexistence. In a relaxed academic atmosphere, participants from both sides of the Iron Curtain could exchange ideas and be exposed to the viewpoints of the 'other side'. As far as can be ascertained, this was the world's first advanced course dedicated to the scientific study of the technological, economic, and political problems associated with nuclear weapons (and their possible demise).

Invigorated by this success, the organisers held a second course in 1968 at Collegio Ghislieri (Pavia), focused on international law and the UN role in disarmament. One of the lecturers - along with Italian physicist Francesco Calogero, who later on chaired Pugwash when it won the Nobel Peace Prize in 1995 - was Vasily Emelyanov, former chairman of the USSR Atomic Energy Commission. Schaerf suggests that Emelyanov must have given a positive report back home, since after Pavia, a Soviet/Russian delegation with leading personalities was present at each meeting (Schaerf 2018). A third course was then organised in 1970 at Duino Castle (Trieste) with Mary Kaldor, Anatol Rapoport, Frank Barnaby, and others. The scope became broader as new topics were added, including chemical and biological warfare and disarmament, security problems of developing countries, and the application of game theory to international policy. ISODARCO was then established and registered as a non-profit association in Rome on 18 January 1972 with the following objectives:

(...) to foster interest for scientific problems related to disarmament and peace with all available means. More specifically it organises, participates in and contributes to meetings, seminars, conferences and professional and cultural refresher courses. It collects documentation, promotes and carries out research on these problems. The Association is not-for-profit and not aligned to any party or political ideology. All proceeds will be used for its institutional goals. ${ }^{4}$

The fourth course (Padua, 1972) saw the participation of Hans Morgenthau, Thomas Schelling, Joseph Goldblat, Herbert York, David Carlton, Jack Ruina and George Rathjens (the latter two had worked on the first US thermonuclear devices), to investigate new technologies and their implications for political and strategic doctrines. By then, the basic structure of ISODARCO was in place: the course directors invited 10-15 lecturers (who received no honorarium, only hospitality) to give a presentation (or two) and then take part in all meetings, contributing to the discussions. Participants (mostly young and at the beginning of their careers) would be selected for their qualifications and provided with accommodation and full board with only a nominal admission fee. Everybody had to provide their own travelling expenses, with only participants from disadvantaged countries receiving some financial support. These rules are still followed today. All these people, with different national, ideological and academic backgrounds, coming together for one or two weeks, created a largely heterogeneous, world-wide knowledge-based network of experts, strong in non-proliferation education.

In the mid-1970s, terrorism was rampant in Europe (with the IRA, the Basque ETA, the German RAF and the Italian Brigate Rosse). The 1974 Urbino course was thus inevitably allocated to that topic, attracting lecturers (including the French Pierre Hassner and Gaston Bouthoul) and participants from 20 different countries. ${ }^{5}$ The same topic was addressed in the 1978 course (Ariccia, Rome). After 9/11, terrorism returned to the ISODARCO agenda several times (2006, 2007, and 2008), with attention to the political and military reactions and their impact on human 
rights. New lecturers, like Matthew Evangelista, spoke to a wide-ranging audience of Israelis, Palestinians, Iranians, Africans, and so on.

The dangers associated with the proliferation of nuclear weapons (but in some cases, also of conventional weapons, including space systems) remained at the core of many successive meetings (Rome 1976, Venice 1980, 1984, and 1988, Verona 1982, San Miniato 1986 and L'Aquila 1990), with Lawrence Freedman and Catherine Kelleher joining the ranks of lecturers. The year 1988 marked a watershed, as the first 'ISODARCO-Beijing Seminar on Arms Control' was held in China (together with the Institute of Applied Physics and Computational Mathematics and the China Institute of Contemporary International Relations). The seminar would be held bi-annually and, after 2004, became the 'PIIC-Beijing Seminar' (to accommodate the acronyms of all the main sponsoring organisations). ${ }^{6}$ A second novelty was the first ISODARCO winter course. So for several years there were annual winter and summer courses, bi-annual seminars in China, and occasional special seminars (in Taipei, Amman, and Venice). However, since 2005, financial constraints forced the organisation to cut back to only the yearly winter course.

The end of the East-West confrontation and the political changes in Russia and Eastern Europe compelled ISODARCO to orient its attention to other forms of conflicts among smaller states, to terrorism, and to the international transfer of military technologies or asymmetric warfare. However, the key interest in nuclear matters came back to the fore after the Prague speech by President Obama in 2009, which reinvigorated the perspective of the final elimination of nuclear weapons. $^{7}$ As a result, ISODARCO devoted the 2009, 2010, and 2011 courses to explore the possibility and consequences of a world without nuclear weapons (Kelleher and Reppy 2011).

The limited progress made in that direction and the worsening relations between the US and Russia required ISODARCO to maintain a focus on the continued challenges of international security posed by the presence and spread of nuclear weapons, their sensitive technologies, and means of delivery. The issue of 'nuclear governance' in a changing security system was the subject of the winter courses of 2014, 2015 and 2016. In the meantime, confirming its forwardlooking agenda, ISODARCO added the military use of cyberspace and autonomous weapons systems (with artificial intelligence) to its list of topics, in Rovereto (1999), Trento (2002) and Andalo $\left(2012,2013\right.$, and 2017). ${ }^{8}$

With limited secretarial and financial assistance, counting mostly on the unremitting, day-to-day support of a few Italian scientists and scholars, ISODARCO has achieved noteworthy objectives, as discussed in the following pages. ${ }^{9}$ As a purely educational institution, it never endorsed particular parties or issued political statements; rather, it wholeheartedly adhered to the founders' assumptions that there is a considerable need to provide sound scientific and technical information to people interested in international politics and security and those wanting to play a more competent role in their activities, as well as to those more actively involved in peace movements and advocacy coalitions. More importantly, ISODARCO's 50-year-long history confirms that problems of war and peace, and those related to arms control and disarmament, are largely political and social issues, and that they therefore require the attention of a large spectrum of diverse disciplines that can only be present in a true, interdisciplinary, global community of non-proliferation experts.

\section{A transnational network of experts for teaching and learning}

As Francis Bacon aptly noted, 'knowledge is power' and therefore whoever has knowledge (or has control over information) has always been in a key position to exert power. This is evident in many spheres of modern society, from economics to ecology: indeed, in the case of the former, it almost seems that economists, like alchemists in the past, possess some kind of 'magic', which is relevant 
to any policy issue. When these knowledge-based, collaborative groups can count on members from different countries, they become 'transnational networks', thus not only boosting their research capabilities (Mabey, Kulich and Lorenzi-Cioldi 2012), but also passing their comprehension of complex issues (such as nuclear disarmament) to students from many different nationalities (Gatt 2009).

The knowledge transfer by the expert network of scholars and scientists participating in the various ISODARCO meetings has been paramount in its main mission to teach and learn about nuclear disarmament. As showed by Nagel (2010), international networks in education have become more and more common, particularly after the success of the Bologna Process (the 'basis' for harmonising European education in all fields). Nonetheless, if peer-to-peer knowledge exchange and transnational expertise networks have become increasingly common in arms control and disarmament education (Buhmann 2007), the literature in the field needs more studies and examples - hence this work on ISODARCO.

'Realist' scholars (e.g. in Baldwin 1993) have regarded education as belonging to 'low politics' issue areas such as the environment or health, not the 'high politics' of foreign and defence policies (economics is probably in between). During the Cold War, political leaders were indeed influenced by the experts, who had to overcome many political obstacles (most notably mutual suspicion) to contribute to 'the long peace' (Gaddis 1987).

This contribution was possible because the technical and scientific nature of causal theories and abstract models as well as the exchange of practical ideas that were presented in international symposia allowed national nuclear experts to appear as apolitical to the leadership of the 'nuclear club'. Scientists were thus perceived as staying clear of 'politics'. Be that as it may, the complexity and uncertainty of the modern world leaves policy-makers no choice but to turn to specialists for advice, specialists who often befriend each other at international conferences, workshops and various meetings, inevitably developing informal networks of expertise.

ISODARCO's organisers never specifically planned for a 'permanent' or formal network of non-proliferation specialists: this phenomenon has been rather the by-product of the many interactions and meetings during the summer and winter courses. As indicators of success, the quality and frequency of meetings among members of the ISODARCO network of experts, as well as the publication records, have been simply remarkable, as showed by Foradori, Giacomello and Pascolini (2018). ${ }^{10}$

Matthew Evangelista of Cornell University, a recurrent participant in the network, notes that although controversial issues in security and arms control are often more political than technical in nature, 'ISODARCO participants, especially the scientists, do seem to find a common language and are able to communicate with mutual respect, even when they disagree. This is especially useful for making progress on controversial issues on which countries disagree'. ${ }^{11}$ And indeed, an important feature of ISODARCO has always been 'the ability to work with colleagues despite the ideological and political disagreements of their countries, and, in particular, with colleagues from the Soviet Union/Russia and China'. ${ }^{12}$

A vivid illustration of the important role of ISODARCO as a network of mutually-trusting experts has been its contribution in developing the Chinese arms control community. As pointed out by Evan S. Medeiros, from the RAND Corporation, in his analysis of the evolution of Chinese strategic thinking, the ISODARCO meetings 'offered Chinese experts their first substantial exposure to international arms-control experts (and vice-versa)' (Medeiros 2007, 220). For several years, these seminars were the only chance in China for Chinese natural scientists and political scientists to meet with one another, and with Western scholars, to openly discuss these politically sensitive issues. How such expert networks impact the policy process and 
inform decisions can be inferred from Medeiros' words on ISODARCO-sponsored courses in 225 China in the 1980s:

The agenda expanded at subsequent meetings, and the atmosphere became more open. US experts used the forum to introduce China's experts to new concepts like de-alerting, and intricacies of theatre missile defence and compliance with the ABM Treaty. Chinese participants also began to share their views on missile proliferation and other sensitive, seldom discussed issues. $(2007,220)$

As to the present time, characterised, as discussed in detail later, by renewed tension between Russia and the West and by a profound crisis of the arms control system, Alexey Arbatov - chair of the Carnegie Moscow Center's Nonproliferation Program and former member of the State Duma - believes ISODARCO continues to play a crucial role as it did during the Cold War. In his opinion, there are two priorities:

The first task of ISODARCO and its allied organizations is to promote public pressure on political leaders of the principal states to wake them up to the nuclear threats. The second mission is for the experts' community of Russia, the United States and its European allies to double their cooperative efforts at elaborating ways and means to salvage what is left from arms control and then restart the whole process. ${ }^{13}$

As far as Italy is concerned, one should also recall the role of ISODARCO's key scientists in opposing any possible scenario of an Italian nuclear arsenal. As evoked by Nadia Arbatova Head of the European Political Studies Department at the Institute for World Economy and International Relations (IMEMO), Russian Academy of Sciences - the main Italian school of nuclear physics had taken a hostile attitude towards military applications of nuclear research at a very early stage, and

two physicists, Francesco Calogero and his former schoolmate and friend Carlo Schaerf, who were in the centre of my research, along with other colleagues got involved in debates over Italy's nuclear future and significantly contributed to the decision of the Italian policy makers to join the Treaty of Non-Proliferation. It was such a great surprise when in the mid-1990s I met both of them in Andalo among other colleagues devoted to the ideas of the Pugwash movement. For me these people are the embodiment of all the best that we have today in the international academic community. ${ }^{14}$

Even in the best circumstances, and even for well-meaning networks of experts, the dissemination of knowledge is never easily accomplished. Furthermore, like Chinese 'mandarins', some scientists and scholars may conclude that to transfer knowledge to the public is not in their best 'interests', because if everyone knew something about something, experts would be less needed. This gives rise to Bacon's 'knowledge is power', a situation where information may be controlled or restricted (thus making room for distortion and manipulation).

It should instead be recognised that if information is shared and passed on to future generations of students, who become more informed citizens, the influence of these networks of experts will further increase. As William C. Potter - founder and director of the James Martin Center for NonProliferation Studies in Monterey, California, the world's leading institution engaged in DNPE aptly writes:

Development of a global disarmament and non-proliferation culture cannot be accomplished easily or quickly. Nor will an influx of money alone solve the problem. What is required is a sustained educational effort as part of a broader strategy to build communities of independent disarmament and nonproliferation specialists. (Potter 2001, 9)

In this respect, ISODARCO has always remained faithful to being an education-oriented network of experts, putting the transfer of knowledge at the core of its whole mission, as discussed in the 
Disarmament and non-proliferation education

The fundamental mission of ISODARCO is advancing knowledge, promoting dialogue, and providing training. Given its traditional focus on nuclear weapon-related issues, the core business of the organisation can be aptly subsumed under the concept of 'disarmament and nonproliferation education (DNPE)'.

The importance of DNPE as a tool in curbing the spread of nuclear weapons, with a view to their elimination, has been recognised since the first special session of the United Nations General Assembly (UNGA) on disarmament issues in $1978 .{ }^{15}$ With resolution 55/33/E of 20 November 2000 , the UNGA returned more vigorously to the issue with a request to the UN Secretary General to prepare, with the assistance of a group of qualified experts, a detailed study. ${ }^{16}$ After two years of preparation, the 'United Nations Study on Disarmament and Non-Proliferation Education' was submitted to the First Committee of the General Assembly at its 57th session on 9 October 2002 and endorsed in the General Assembly. ${ }^{17}$

The study starts from the recognition that disarmament education is an integral part of peace education and that the need for DNPE has never been greater. The overall purpose of DNPE is described as 'impart[ing] knowledge and skills to empower individuals to make their contribution, as national and world citizens, to the achievement of general and complete disarmament under effective international control'. ${ }^{18}$ The study emphasises the continued and growing significance of nonproliferation of weapons of mass destruction (WMD) and the need for new thinking to address the security challenges of the post-Cold War environment. It tackles new elements, such as the great potential of innovative pedagogical methods in connection with new information and communication technologies, particularly the internet; the importance of introducing DNPE into post-conflict situations as a contribution to peace-building; and the great need to introduce gender perspectives into security issues, and specifically into non-proliferation. Moreover, the study contains 34 specific recommendations for action to be undertaken by governments, regional organisations, the UN, and other international organisations, as well as municipal and religious leaders. ${ }^{19}$ It also seeks to establish close collaboration between experts and civil society, practitioners, and scholars, including educators and academic institutions mainly at the secondary and tertiary levels of education.

While the UN initiative has received wide support, its implementation has lagged behind, with DNPE continuing to be a largely underutilised (and underfinanced) tool for promoting peace, disarmament, and non-proliferation (Sokova 2012). The trouble is, again in the words of William C. Potter, that the two emerging post-Cold War disarmament challenges are ignorance and complacency. With the end of the bipolar system and the diminution of the traditional danger of superpower nuclear conflict, a mistaken perception has spread that there are no longer any real nuclear dangers (Potter 2001). This reading of current security is dangerously flawed. Even if we have likely escaped the danger of a thermonuclear war between superpowers, the presence and proliferation of WMD continue to pose a serious threat to today's global security. The fight against nuclear proliferation is still long and uncertain, and disarmament remains a very long-term objective. Meanwhile, the risk of actual use continues to be high. Notwithstanding deep cuts in the US and Russian arsenals since the end of the Cold War, the 16,000 nuclear weapons still in existence, some of which are mounted on ballistic missiles ready to be launched, are a potent reminder of the immediate capability of world annihilation. Nowadays, weapons of mass destruction and their delivery vehicles are still perceived by many countries as necessary or highly desirable armaments for a variety of reasons, including serving as deterrents to security threats, as a force equaliser compensating for conventional military capabilities, as prestige and status enhancers, and for bolstering regime security (Foradori 2014). 
In this volatile and evolving 'nuclear context', combating ignorance, complacency, and a culture of violence through DNPE continues to be a task of critical relevance. As the then UN Secretary-General, Kofi Annan, rightly highlighted, 'what we know little about, we care little to do anything about'. ${ }^{20}$ The very limited awareness of the risks of nuclear proliferation concerns not only the general public but also otherwise well-educated citizens. Experts in arms control and disarmament are in short supply in both developing and developed countries, including nuclear weapons states. The old generation of scholars and practitioners increasingly complain that very few younger experts are available to replace them (Sokova 2012,18). An entire new generation is growing up without the clear perception of the risks posed by nuclear weapons, wrongly deemed as relics of the Cold War, while non-proliferation studies have become a marginal and neglected field of research and teaching in most colleges and universities. With each passing year, there are also fewer opportunities to access the living memory of the hibakusha (the surviving victims of the 1945 atomic bombings of Hiroshima and Nagasaki), who are able to provide fundamental testimony of the catastrophic and inhumane consequences of nuclear weapons usage. The scant interest in disarmament also concerns policy-makers, who tend to be uninterested in and woefully uneducated about non-proliferation and disarmament issues. To aggravate the matter, being fixated on quick solutions to immediate crises, governments tend not to invest adequately in longterm training programmes (Potter 2001, 5).

Fully cognisant of this troubling situation, ISODARCO's contribution to DNPE has been continuous since 1966. As Carlo Trezza, former Ambassador for Disarmament and Non-Proliferation, who chaired the Missile Technology Control Regime (MTCR), the Conference on Disarmament in Geneva and the UN Secretary General's Advisory Board on Disarmament Matters in New York, has recently observed:

Ever since its establishment, when the Cold War and nuclear arsenals were at their peak, ISODARCO has played a unique and indispensable role in raising the awareness of the increasing risks of a nuclear war and of an arms race. It has maintained its engagement all throughout the years of the East-West detente and it is as active as ever today when a new arms modernization spiral looms on the horizon. ${ }^{21}$

As previously mentioned, this contribution has resulted in 53 summer/winter courses (all but one held in Italy), four special seminars (two in Taipei, one in Amman and one in Venice), and, in cooperation with Chinese colleagues, 15 seminars in China. In total, about 3,000 speakers and participants from some 80 different countries have attended these activities. Over the past 20 years, the flagship ISODARCO educational event has been the winter course. ${ }^{22}$ The typical course features some 15-20 speakers and some 80 participants, mostly postgraduate and $\mathrm{PhD}$ students, from about 20 different nationalities. Examining this experience closely, we see that several distinctive features characterise ISODARCO's role in DNPE in terms of values, objectives, and methodologies, even when compared to similar educational events.

First of all, ISODARCO's courses distinguish themselves for their comprehensiveness and depth in addressing the questions at stake. Contrary to prevailing standards in international disciplinary conferences, workshops, and short courses - where issues tend to be swiftly, and often superficially, presented and discussed - ISODARCO's educational approach gives preference to longer and more intense working sessions of 1.5 hours, where single issues are thoroughly analysed. ${ }^{23}$ Panels with multiple speakers are rare, and the typical ISODARCO session features one single speaker with deep knowledge in the topic of concern who presents for 45 minutes under the Chatham House Rule. ${ }^{24}$ The issue is then exhaustively discussed in a 45- minute Q and A moderated by the session's chair, normally an experienced ISODARCO participant or another speaker, who facilitates in an atmosphere of impartiality and mutual respect through discussion 
and collaborative analysis. As noted by the former ambassador of Iran to the International Atomic Energy Agency (IAEA), Ali Asghar Soltanieh, 'allowing ample time for deepening discussion of complex and often controversial subjects is indeed one of the major strengths of ISODARCO's courses'. ${ }^{25}$

To cope with such an extended and in-depth programme, speakers must be true experts in their subject matter and the list of speakers does indeed include some of the all-time greatest nonproliferation and disarmament figures, who have contributed in fundamental ways to shaping policies, strategies, theories, scholarly work, and debates in the nuclear field. ${ }^{26}$

A second distinguishing feature of ISODARCO's form of DNPE is the significant emphasis on the scientific and technical dimensions of nuclear issues, whose sound understanding is believed to be essential to fully grasp the true nature of nuclear weapons and strategies, as well as for developing effective policies of control, non-proliferation, and disarmament. ISODARCO's vision of its educational role is firmly at the intersection of science and policy. The winter courses introduce natural scientists to the language and perspectives of social scientists and policy-makers, and vice-versa, thus bridging cultural divides within the community of non-proliferation experts. As the Italian group of the Pugwash Conferences on Science and World Affairs, ISODARCO shares the mission 'to bring scientific insight and reason to bear on, namely, the catastrophic threat posed to humanity by nuclear and other weapons of mass destruction'. ${ }^{27}$ As part of this attempt at bridging the science/policy divide, ISODARCO truly believes in interdisciplinary work and brings together nuclear experts from a variety of disciplines, ranging from physics to engineering, from international relations, to history, to international law.

Third, ISODARCO is particularly effective in promoting conversation and interaction between scholars and practitioners. This provides participants with a very balanced view of theory and practice, thus offering an appropriate forum to present and discuss ideas and opinions without losing sight of reality. The fine mix of scholars and practitioners in each ISODARCO course helps generate 'actionable knowledge', whereby practical knowing, or scholarly practice, aims at identifying problems, examining them closely, and searching for doable solutions. From this perspective, knowledge is simultaneously driven by scientific interest, civic commitment, and ethical conduct. As Ambassador Ali Asghar Soltanieh again aptly put it, 'the combination of both academia and practitioners as lecturers gives a unique opportunity for exchange of experience along with principles and theories'. ${ }^{28}$

Fourth, ISODARCO's pedagogy is based on the assumption that informed dialogue and training cannot be ideological and must be open to multiple points of view. ISODARCO's speakers and participants are only united by the sense of urgency about the nuclear threat and the need to appropriately understand it in the search for possible remedies. Beyond that, however, they have very different mindsets, come from very diverse cultural and professional backgrounds, express a plurality of political opinions and values, and do not necessarily share the same ideas about how to curb proliferation and make progress toward the ultimate goal of nuclear abolition. Within ISODARCO, this diversity is considered healthy and beneficial for producing knowledge and for promoting dialogue and creative thinking that can lead to novel ideas and workable solutions. As Judith Reppy, Professor Emerita at Cornell University, remarked, 'ISODARCO provides the opportunity to hear security issues discussed in a truly international setting, one in which many points of view are present, unlike much of the discussion in the US' ${ }^{29}$ In this regard, it is worth recalling that ISODARCO has never endorsed any particular political position and all presentations at its events have been made in the speaker's personal capacity and not as a representative of ISODARCO or the institutions to which the speaker belonged. 
Fifth, utmost attention and respect are paid to the passing of knowledge and expertise to the younger participants. Intergenerational connection lies at the core of ISODARCO's mission. If DNPE concerns all stages of education, ISODARCO's specific target is the university level, specifically postgraduate and PhD students. All the features of ISODARCO's approach to DNPE just discussed are very relevant in relation to training the 'next generation of nuclear specialists'. As noted by Roberta Mulas, a $\mathrm{PhD}$ student in non-proliferation studies at Warwick and Luiss universities, who attended several winter courses, 'ISODARCO is a great forum for young professionals and students to get to listen to and interact with leading experts in the field of non-proliferation and disarmament'. ${ }^{30}$ According to Tariq Rauf, former Head of the Verification and Security Policy Coordination Office at the IAEA and now Director of the Stockholm International Peace Research Institutes Disarmament, Arms Control and Non-Proliferation Programme, ISODARCO's strength in comparison to other DNPE initiatives is that 'the residential format in a secluded location promotes collegiality and an informal setting for closer interaction between participants and presenters' ${ }^{31}$

The fact that all speakers stay in Andalo for the entire duration of the course, and not just for a few hours on the day of their presentation, is common practice, and a major added value, so allowing ample time for meeting, discussion, and networking. The relaxed and friendly atmosphere of ISODARCO - Ambassador Soltanieh made also reference to the unique 'Italian hospitality and style as a key ingredient for success, ${ }^{32}$ - coupled with common meals without seating arrangements, the opportunity to practice winter sports together and long late-night discussions, makes conversation and interaction between senior and junior participants unusually easy, intense, and fruitful. ${ }^{33}$ According to Sylvain Fanielle, currently junior legal officer at the IAEA, who attended ISODARCO while a $\mathrm{PhD}$ student in non-proliferation at the University of Antwerp:

When you start your career in the field of non-proliferation and disarmament, learning from and exchanging with experienced and renowned scholars or professionals is essential. ISODARCO offers this informal platform in which all these experts are available to discuss with young professionals ideas which could enhance the non-proliferation and disarmament regime. ${ }^{34}$

Again, in the words of Roberta Mulas, 'in my experience, at ISODARCO I have received generous feedback on my research by some of the most relevant people who could comment on it, but this did not happen during official presentations, but rather at the dinner table or on the ski slopes'. ${ }^{35}$

The impact of ISODARCO in raising Italy's 'next generation of nuclear specialists' has been particularly significant. Non-proliferation studies have been dramatically neglected in Italy, and for many Italian students and junior researchers, ISODARCO has been, and to a large extent continues to be, a privileged forum in which to receive training and profit from exposure to nuclear experts and peers. According to Stefano Borgiani, who attended ISODARCO as a young student and who is now junior advisor in the Disarmament, Arms Control and Non-Proliferation Division at the Italian Ministry of Foreign Affairs and International Cooperation:

Nowhere else in Italy could I meet world-class experts and be updated on the very latest events in nuclear affairs, from Chinese modernisation to North Korean nuclear tests. Equally important, ISODARCO has been an indispensable experience in which to make contacts and be integrated into what is labelled the non-proliferation community. Again, nowhere else in Italy, but in Andalo, could I meet and interact directly with dozens of nuclear scholars, whose books are in my library. ${ }^{36}$

Finally, ISODARCO's extensive research and dissemination activities are to be considered an integral part of its contribution to DNPE. These have resulted in the publication of 29 books by quality publishing houses, including Palgrave Macmillan, Routledge, John Wiley, St Martin's Press, Dartmouth/Ashgate, Croom Helm, and Stanford University Press. ${ }^{37}$ 


\section{Conclusion}

The aim of this article was to examine ISODARCO's contribution to the international community's efforts in halting the proliferation of nuclear weapons and informing an audience broader than that of non-proliferation experts about the important achievements of this small and littleknown Italian NGO during a half-century of continuous engagement in disarmament and nonproliferation education and training.

The history of ISODARCO appears remarkable. As shown, its great contribution has been the promotion of education and critical thinking on nuclear weapons-related issues, a direct engagement in advocacy and in building a social movement to work towards achieving enhanced national and international security at lower levels of armaments, and ultimately general and complete disarmament under effective international control. As the 2002 UN Study notes, the development of global disarmament and non-proliferation education and culture cannot be accomplished easily, cheaply, or quickly, therefore a major effort is required to build communities of independent disarmament and non-proliferation specialists. ${ }^{38}$ The 50-year ISODARCO experience is indeed a successful example of a transnational community of experts engaged in combating the proliferation of nuclear weapons through education and training. It is striking just how much can be done, even in the realm of security and high politics, with few material resources, but with the outstanding commitment and enthusiasm of a few talented individuals (i.e., the handful of people who have run ISODARCO for five decades, starting with its founder and director Carlo Schaerf).

To emphasise the importance of the achievements detailed in the article, President Obama's words, once again, provide an effective conclusion:

The task of building a safer future requires people from around the world to engage in peaceful collaboration. For half a century, ISODARCO has brought women and men of different backgrounds and beliefs together to study and discuss pressing security concerns. By identifying problems, engaging in debate, and working in a spirit of common purpose to address issues ranging from the threat of nuclear weapons to conflict in cyberspace and the need for greater international cooperation, you are helping reduce the possibility of catastrophe and contributing to better understanding among peoples and states. ${ }^{39}$

\section{Acknowledgements}

The authors wish to thank Alessandro Pascolini for his contribution to this article, and Carlo

\section{Notes on contributor}

Paolo Foradori is Associate Professor in Political Science at the School of International Studies and the Department of Sociology and Social Research at the University of Trento, Italy. From 2009 to 2011, he was Marie Curie fellow at the Center for Nonproliferation Studies, Monterey Institute of International Studies, California, and until 2014 an associate of the Project on Managing the Atom at the Belfer Center for Science and International Affairs at Harvard University's Kennedy School of Government.

Giampiero Giacomello is Associate Professor of Political Science at the Department of Political and Social Sciences, University of Bologna. He has been visiting professor at various US and European universities, coeditor of Defence Studies and contributor to Freedom House's Freedom on the Net for five years.

\section{Notes}

1. Personal letter by US President Barack Obama to Carlo Schaerf, founder and president of ISODARCO, 2 June 2016. The text of the letter can be found on the ISODARCO webpage at: http://www.isodarco.it/ $\mathrm{html} / \mathrm{OBAMA160602.pdf}$. It is worth recalling that President Obama was awarded the Nobel Peace Prize 
in 2009 especially for his 'vision of and work for a world without nuclear weapons' (http://www. nobelprize.org/nobel_prizes/peace/laureates/2009/press.html).

2. An image of the medal and the accompanying letter by the General Secretariat of the Presidency of the Republic are available on the ISODARCO webpage at: http://www.isodarco.it/html/lettPdR-Iso2017. pdf.

3. ISODARCO is the Italian Pugwash group. For more on Pugwash and the relationship with ISODARCO see the third part of this article.

4. ISODARCO's statute is available at the organisation's webpage at: http://www.isodarco.it/html/ iso_statute.html.

5. The proceedings of the course were collected and published in one of the early volumes to tackle terrorism (Carlton and Schaerf 1975, reprinted in 2015; see also Schaerf et al. 1992).

6. The key contribution of ISODARCO to the development of the Chinese arms-control community is discussed more in detail in the second part of the article.

7. Office of the Press Secretary 'Remarks by the President Barack Obama', Hradcany Square, Prague, Czech Republic, 5 April 2009, http://www.whitehouse.gov/the_press_office/Remarks-By-President-BarackObama-In-Prague-As-Delivered/.

8. The choice of the topic and the designation of the directors for each course is a prerogative of the ISODARCO president. His/her decision is also based on input from the participants and lecturers, who are invited to provide suggestions in the closing session of each course (personal communication with Carlo Schaerf, 15 December 2017).

9. Fifty years of ISODARCO continuous activity have been made possible by the financial support provided by major foundations, mainly the John D. and Catherine T. MacArthur Foundation and the Ford Foundation, universities and research institutions, national and local authorities, and some individual donors. Among those deserving of special mention are the Carnegie Endowment for International Peace and the Carnegie Corporation of New York, the Volkswagen Foundation, the Italian National Research Council (CNR), the universities of Rome 'Tor Vergata' and Trento, and several local institutions in the Trentino province.

10. As a spin-off of ISODARCO's meetings, Ambassador Trezza created and continues to maintain, since 2012, a mailing list of Italian nuclear experts where information, papers and opinions on nuclear-related matters are exchanged as well as discussed. This group, called 'Rete italiana sul disarmo, nonproliferazione e sicurezza', was largely based on regular attendees at ISODARCO's courses, where those on the mailing list could meet in person at least once a year. Interestingly, Federica Mogherini, former Italian Minister of Foreign Affairs and currently High Representative of the European Union for Foreign Affairs and Security Policy, has been part of the group (although she stopped her active participation since she took office as Minister of Foreign Affairs in 2014).

11. Personal communication, 13 October 2016.

12. Ibid.

13. Personal communication, 22 December 2016.

14. Personal communication, 18 December 2016.

15. https://unoda-web.s3-accelerate.amazonaws.com/wp-content/uploads/2016/07/Final-document-SSODI-1978.pdf.

16. http://www.un.org/ga/search/view_doc.asp?symbol=A/RES/55/33.

17. United Nations, United Nations Study on Disarmament and Non-Proliferation Education, A/57/124, of 30 August 2002.

18. Ibid., art. 6.

19. To review the implementation of the recommendations by states, international organisations and NGOs, the Secretary-General produces biennial reports. The reports are available at: http://www.un.org/ disarmament/education/sg-reports.html

20. United Nations, United Nations Study on Disarmament and Non-Proliferation Education, 55/33 E of 20 November 2000, 4.

21. Personal communication, 15 December 2016.

22. The course is structured as six full working days and traditionally takes place in the second week of January in Andalo, a ski resort in the Italian Alps near Trento (altitude over 1,000m). It should be noted that local communities where ISODARCO courses have taken place never participated actively in the educational or advocacy activities of the organisation, and only rarely provided a limited amount of funds to the organisation (personal communication with Carlo Schaerf, 28 November 2017). 
23. Reading materials are also made available by the speakers to participants in advance on the ISODARCO webpage.

24. When a meeting is held under the Chatham House Rule, participants are free to use the information received, but neither the identity nor the affiliation of the speaker(s), nor that of any other participant, may be revealed. By providing anonymity to speakers, this encourages open and free discussion and the sharing of information (https://www.chathamhouse.org/about/chatham-house-rule).

25. Personal communication, 9 December 2016.

26. Among the hundreds who lectured at ISODARCO over a period of five decades, one can name three Nobel laureates: Jack Steinberger, Thomas Schelling and Joseph Rotblat; prominent scientists, some of whom directly participated in the development of the bomb and later in efforts to its control - Edoardo Amaldi, Carlo Calogero, Bernard Feld, Richard Garwin, Frank von Hippel, Herbert York; diplomats and policy-makers who were instrumental in creating the current international non-proliferation regime George Bunn, Jacek Bylica, Paolo Cotta-Ramusino, Alexander Kmennt, Laura Rockwood, Tariq Rauf, Tibor Toth, Carlo Trezza; scholars such as Hans Morgenthau, the father of the academic discipline of International Relations, and Anatol Rapoport, a world pioneer in game theory and conflict resolution; leading non-proliferation academics and experts - James Acton, Alexei Arbatov, Avner Cohen, Matthew Evangelista, Lynn Eden, Mark Fitzpatrick, Lawrence Freedman, David Holloway, Catherine McArdle Kelleher, Rebecca Johnson, Jeffrey Lewis, Sverre Lodgaard, Steven Miller, Harald Müller, Joseph Pilat, Tom Sauer, Etel Solingen, Nina Tannenwald, William Walker, and many others. This list of names is inevitably very partial and arbitrary, and was made by the authors in alphabetical order with the only purpose of giving a sense of the quality of the speakers who have been involved in ISODARCO's courses. It is worth mentioning that many of those experts, given their vast professional experience, could equally be classified as scientists, scholars or policy-makers.

27. https://pugwash.org/about-pugwash/. The Pugwash Conferences on Science and World Affairs is an international organisation founded in 1957 by Joseph Rotblat and Bertrand Russell in Pugwash, Nova Scotia, Canada, following the release of the Russell-Einstein Manifesto in 1955. It was in recognition of its efforts to 'diminish the part played by nuclear arms in international politics and, in the longer run, to eliminate such arms' that Pugwash and its co-founder, Sir Joseph Rotblat, were awarded the 1995 Nobel Peace Prize (https://www.nobelprize.org/nobel_prizes/peace/laureates/1995/press.html). As a result of the significant Italian presence in Pugwash (international), there is not an institutionalised national Pugwash in Italy, as in several other countries word-wide. In this respect, ISODARCO is not formally linked to Pugwash, but it is traditionally de facto considered its Italian manifestation, as clarified by Carlo Schaerf, who also confirmed the frequent and very positive relations between the two institutions (personal communication, 19 September 2016).

28. Personal communication.

29. Personal communication, 10 December 2016.

30. Personal communication, 14 December 2016.

31. Personal communication, 12 December 2016.

32. Personal communication, 9 December 2016.

33. This feature was underscored also by Matthew Evangelista when he praised as a major advantage "the mix of formal lectures, informal discussion over dinner or drinks, and participant-initiated workshops and seminars outside the official program' (personal communication).

34. Personal communication 17 December 2016.

35. Personal communication, 14 December 2016

36. Personal communication, 6 March 2017.

37. On the occasion of ISODARCO's 50th anniversary, an annotated collection of the best 20 contributions on nuclear armaments and disarmament from those books was republished in Foradori, Giacomello and Pascolini 2018.

38. United Nations, United Nations Study, 2000, art. 10.

39. Personal letter from US President Barack Obama to Schaerf.

\section{References} University Press. 
Buhmann, C.B. 2007. “The Nuclear Weapons Inheritance Project: Student-to-Student Dialogues and 615 Interactive Peer Education in Disarmament Activism', Medicine, Conflict and Survival 23 (2): 616 $92-102$.

Carlton, D., and C. Schaerf, eds. 1975. International Terrorism and World Security. New York: John Wiley reprinted by Routledge Library Editions 2015.

Foradori, P. 2014. 'Introduction'. In Still the Century of Overkill? Strengthening the Control of Weapons of Mass Destruction, edited by P. Foradori, 13-25. Baden-Baden: Nomos.

Foradori, P., ed. 2013. Tactical Nuclear Weapons and Euro-Atlantic Security: the Future of NATO. London 622 and New York: Routledge.

Foradori, P., G. Giacomello, and A. Pascolini, eds. 2018. Arms Control and Disarmament: 50 Years of 624 Experience in Nuclear Education. Cham, Switzerland: Palgrave Macmillan. 625

Gaddis, J.L. 1987. The Long Peace: Inquiries into the History of the Cold War. Oxford: Oxford University 626 Press.

Gatt, S. 2009. 'Networking School Teachers to Promote Better Practice in the Teaching of Science Across Europe'. European Journal of Education 44 (4): 493-506.

Kelleher, C., and J. Reppy, eds. 2011. Getting to Zero: The Path to Nuclear Disarmament. Stanford: Stanford University Press.

Mabey, C., C. Kulich, and F. Lorenzi-Cioldi 2012. 'Knowledge Leadership in Global Scientific Research'. The International Journal of Human Resource Management 23 (12): 2450-2467.

Medeiros, E.S. 2007. Reluctant Restraint: The Evolution of China's Nonproliferation Policies and Practices, 1980-2004. Stanford: Stanford University Press.

Nagel, A.-K. 2010. 'International Networks in Education'. In Education in Political Science: Discovering a Neglected Field, edited by A.P. Jakobi, K. Martens, and K.D. Wolf, 156-174. New York: Routledge/ ECPR Studies in European Political Science.

Norris, R.S., and H.M. Kristensen 2010. “Global Nuclear Weapons Inventories, 1945-2010”. Bulletin of the Atomic Scientists 66 (7): 77-83.

Potter, C.W. 2001. 'A new agenda for disarmament and non-proliferation education'. Disarmament Forum $3: 5-12$.

Rubbia, C. 1991. Edoardo Amaldi: Scientific Statesman. Geneva: CERN.

Schaerf, C. 2018. 'Afterword'. In Arms Control and Disarmament: 50 Years of Experience in Nuclear Education, edited by P. Foradori, G. Giacomello, and A. Pascolini. Cham, Switzerland: Palgrave Macmillan.

Schaerf, C., G. De Lutiis, A. Silj, F. Carlucci, F. Bellucci, and S. Argentini 1992. Venti anni di violenza politica in Italia 1969-1988, Cronologia ed analisi statistica Rome: Università degli Studi di Roma 'La Sapienza', Centro Stampa d'Ateneo.

Sokova, E. 2012. 'Disarmament and Non-Proliferation Education. Recent Developments and the Way Forward'. CTBTO Spectrum 19 (September): 16-18.

\section{Italian summary}

L'educazione al disarmo e alla non proliferazione è uno strumento chiave per contrastare la diffusione delle armi nucleari, in vista di una loro completa eliminazione. L'articolo esamina la straordinaria storia dell'International School on Disarmament and Research on Conflicts (ISODARCO) in occasione del suo cinquantesimo anniversario di impegno continuo nelle attività di formazione e training. ISODARCO offre un forum unico dove esperti nucleari provenienti da diversi background e approcci possono incontrarsi, discutere e promuovere l'azione come una rete transnazionale di esperti basata sulla conoscenza e, cosa ugualmente importante, trasmettere le proprie competenze alla 'next generation of non-proliferation specialists'. Il contributo di questa piccola ONG italiana è davvero degno di nota, apprezzato a livello nazionale e soprattutto internazionale, e merita di essere conosciuto da un pubblico ben più ampio rispetto ai soli esperti di non proliferazione e disarmo. 